\title{
Temperature requirements for growth and survival of macroalgae from Antarctica and southern Chile
}

\author{
C. Wiencke ${ }^{1}$, I. tom Dieck ${ }^{2}$ \\ ${ }^{1}$ Institute of Polar and Marine Research, Am Handelshafen 12, D-2850 Bremerhaven, Federal Republic of Germany \\ ${ }^{2}$ Biologische Anstalt Helgoland, Notkestraße 31, D-2000 Hamburg 52, Federal Republic of Germany
}

\begin{abstract}
Optimum and limiting temperature demands for growth and survival were determined in 14 species from the Antarctic/cold-temperate region and in 7 cold-temperate species from southern Chile. The growth response was tested in steps of $5^{\circ} \mathrm{C}$ from 0 to $25^{\circ} \mathrm{C}$. In Antarctic/cold-temperate macroalgae 4 groups with different temperature-growth-ranges could be distinguished. The highest possible growth temperature was $5^{\circ} \mathrm{C}$ in Iridaea cordata (Group 1), $10^{\circ} \mathrm{C}$ in Geminocarpus geminatus, Ulothrix subflaccida and the female gametophyte of Desmarestia menziesii (Group 2), $15^{\circ} \mathrm{C}$ in Adenocystis utricularis, Scytothamnus fasciculatus, Urospora penicilliformis and Acrosiphonia arcta (Group 3) and $20^{\circ} \mathrm{C}$ in Prasiola crispa ssp. antarctica f. antarctica, Ulothrix implexa and Enteromorpha bulbosa (Group 4). Maximum survival temperatures of 14 to 19 (up to 25$)^{\circ} \mathrm{C}$ were found in those species growing up to 10 or $15^{\circ} \mathrm{C}$. Species growing up to $20^{\circ} \mathrm{C}$ tolerated 24 to $28^{\circ} \mathrm{C}$. Maximum survival temperature in Gigartina skottsbergii was $15^{\circ} \mathrm{C}$, and in Leptonematella falklandica (nov. comb., formerly Leptonema falklandicum) and Pilayella littoralis 22 to $24^{\circ} \mathrm{C}$ (growth not determined in these 3 species). Species with exclusively temperate distribution can be divided into 2 groups: The more stenotherm species Iridaea laminarioides, I. undulosa and a ligulate Desmarestia sp. grew between $(0 \text { or) } 5 \text { and } 15 \text { (or } 20)^{\circ} \mathrm{C}$ (Group 1). The more eurytherm species Chordaria magellanica, Ectocarpus siliculosus, Enteromorpha clathrata and Scytosiphon lomentaria (Group 2) had an extended growth range from $0^{\circ} \mathrm{C}$ up to 20 (or 25$)^{\circ} \mathrm{C}$. Growth at $0^{\circ} \mathrm{C}$ was very reduced or not possible in all cold-temperate species except for $C$. magellanica and E. siliculosus. The maximum survival temperatures of these species were 17 to $24^{\circ} \mathrm{C}$. The evolution of cold water macroalgae in Antarctica from cold-temperate species probably started after opening of the Drake Passage and the concomitant temperature lowering in Antarctica some 25 to 30 million yr ago. It is still in process today as indicated in A. utricularis. In macrothalli of this species from Antarctica and southern Chile ecotypes were demonstrated exhibiting different temperature optima for growth (at 10 and $15^{\circ} \mathrm{C}$ ) and different upper survival temperatures (at 18 and $19^{\circ} \mathrm{C}$.
\end{abstract}

\section{INTRODUCTION}

Endemic Antarctic macroalgae show a temperature requirement for growth between 0 and 10 (or 15$)^{\circ} \mathrm{C}$, optimum growth values at 0 to 5 (or 10$)^{\circ} \mathrm{C}$ and maximum survival temperatures of 11 to $18^{\circ} \mathrm{C}$ (Ohno 1984 , Wiencke \& tom Dieck 1989). These low temperature demands were inferred to be dependent on the long cold water history (25 to 30 million yr) of Antarctica triggering the development of cold water taxa (Wiencke \& tom Dieck 1989). Macroalgae distributed in Antarctic and/or cold temperate regions may still be in the process of adaptation to low temperatures. So it is of particular interest to compare the temperature demands of species with Antarctic/cold-temperate and exclusively temperate distribution. Data on the temperature demands of such macroalgae are available for Pilayella littoralis (Müller \& Stache 1989) and Durvillaea antarctica (Délépine \& Asensi 1976). The aim of this study was to describe the temperature requirements for growth of 21 red, brown and green algal species from Antarctica and southern Chile.

\section{MATERIAL AND METHODS}

The macroalgae investigated were isolated as spores during 2 expeditions to King George Island (Antarctica; Clayton \& Wiencke 1986, Wiencke 1988) and to southern Chile and subsequently cultivated in home 
laboratories. The algae are listed in Table 1 Cultivation methods, growth rates and upper survival temperatures were obtained as described elsewhere (Wiencke \& tom Dieck 1989).

\section{RESULTS}

The investigated Antarctic/cold-temperate species can be classified into 4 groups according to their temperature-growth characteristics.

Group 1: The gametophyte of Iridaea cordata was able to grow at up to $5^{\circ} \mathrm{C}$ (Fig. 1). At $10^{\circ} \mathrm{C}$ positive growth rates were recorded in the first 3 wk of the experiment, but later turned to negative values accompanied by bleaching of the upper thallus parts. The upper survival temperature of $I$. cordata gametophytes was 14 to $16^{\circ} \mathrm{C}$ (Table 2)

Group 2: Geminocarpus geminatus (Fig. 2), Desmarestia menziesii (female gametophyte; Fig. 3) and Ulothrix subflaccida (Fig. 4) grew between 0 and $10^{\circ} \mathrm{C}$ with peak growth rates at $5^{\circ} \mathrm{C}(G$. geminatus, D. menziesii) or $10^{\circ} \mathrm{C}$ (U. subflaccida). The upper temperature tolerance of all subtidal and lower sublittoral species and of Gigartina skottsbergii was 14 to $17^{\circ} \mathrm{C}$. The only alga of this group from the upper intertidal, $U$. subflaccida, survived up to 23 to $25^{\circ} \mathrm{C}$ (Table 2 ).

Group 3: The temperature demands of the isolates of Adenocystis utricularis from Antarctica and southern Chile were slightly different. Macrothalli of both isolates grew between 0 and $15^{\circ} \mathrm{C}$. The temperature growth optimum in the Antarctic isolate was $10^{\circ} \mathrm{C}$ (Fig. 5), but $15^{\circ} \mathrm{C}$ was optimal in the south Chilean isolate (Fig. 6). The maximum survival temperature of Antarctic A. utricularis was $18^{\circ} \mathrm{C}$ and that from south Chile was $19^{\circ} \mathrm{C}$ (Table 2). Scytothamnus fasciculatus (Fig. 7), Urospora penicilliformis (Fig. 8) and Acrosiphonia arcta (Fig. 9) grew between 0 and $15^{\circ} \mathrm{C}$ $S$. fasciculatus showed very uniform growth rates at all temperatures tested, which were maintained over an experimental period of $3 \mathrm{mo}$; $U$. penicilliformis and $A$. arcta grew optimally at $5^{\circ} \mathrm{C}$. The maximum survival temperatures were $19^{\circ} \mathrm{C}$ for $U$. penicilliformis and $A$. arcta and 22 to $24^{\circ} \mathrm{C}$ for S. fasciculatus, Leptonematella falklandica and Pilayella littoralis (Table 2) (growth rates were not determined for these 3 species).

Group 4: Prasiola crispa ssp. antarctica (Fig. 10), Ulothrix implexa (Fig. 11) and Enteromorpha bulbosa (Fig. 12) grew between 0 and $20^{\circ} \mathrm{C}$. The maximum survival temperatures of these species were 24 to $28^{\circ} \mathrm{C}$ (Table 2)

Macroalgae with exclusively temperate distribution can be divided into 2 groups with different temperature demands for growth, one with more stenothermal, the second with more eurythermal characteristics. Group 1 consists of a ligulate Desmarestia sp., Iridaea undulosa and I. laminarioides. Gametophytes of the ligulate Desmarestia sp. grew from 0 to $20^{\circ} \mathrm{C}$ with very low rates at $0^{\circ} \mathrm{C}$ and a pronounced optimum at $15^{\circ} \mathrm{C}$ (Fig. 13). The sporophyte of this species grew only from 5 to $20^{\circ} \mathrm{C}$, with a growth peak at $15^{\circ} \mathrm{C}$ (Fig. 14). I. laminarioides gametophytes grew between 0 and $15^{\circ} \mathrm{C}$ with low rates at $0^{\circ} \mathrm{C}$ and a maximum between 10 and $15^{\circ} \mathrm{C}$ (Fig. 15). The temperature growth limits for $I$. undulosa gametophytes were 5 and $15^{\circ} \mathrm{C}$ (Fig. 16)

The more eurythermal second group consists of Chordaria magellanica, Ectocarpus siliculosus, Enteromorpha clathrata and Scytosiphon lomentaria. C. magellanica grew from 0 to $20^{\circ} \mathrm{C}$ showing a slight maximum at 5 to $10^{\circ} \mathrm{C}$ (Fig. 17). E. siliculosus grew at all temperatures from 0 to $20^{\circ} \mathrm{C}$ with a broad maximum between 5 and $15^{\circ} \mathrm{C}$ (Fig. 18). E. clathrata was also able to grow from 0 to $20^{\circ} \mathrm{C}$, with a growth plateau between 5 and $15^{\circ} \mathrm{C}$ and with very reduced growth rates at 0 and $20^{\circ} \mathrm{C}$ (Fig. 19). A similar growth pattern was shown by $S$. lomentaria with a broad maximum between 5 and $20^{\circ} \mathrm{C}$ and reduced growth rates at 0 and $25^{\circ} \mathrm{C}$ (Fig. 20).

The maximum survival temperatures of most temperate algae were between 21 and $24^{\circ} \mathrm{C}$ (Table 2). The blades of Iridaea undulosa and $I$. laminarioides had a somewhat lower temperature tolerance of $17^{\circ} \mathrm{C}$, but the holdfasts of $I$. undulosa survived $22^{\circ} \mathrm{C}$ (Table 2).

\section{DISCUSSION}

The Antarctic/cold-temperate species grow between 0 and 5,10 or $15^{\circ} \mathrm{C}$ exhibiting relatively uniform optima at 5 or $10^{\circ} \mathrm{C}$ and maximum survival temperatures of 14 to 19 (up to 25$)^{\circ} \mathrm{C}$. Only the supratidal species Prasiola crispa ssp. antarctica and the intertidal species Enteromorpha bulbosa and Ulothrix implexa show higher temperature limits for growth $\left(\leq 20^{\circ} \mathrm{C}\right)$ and survival $\left(24\right.$ to $\left.28^{\circ} \mathrm{C}\right)$. Another intertidal species, Pilayella littoralis, from Diego Ramirez Island grows between 2 and $20^{\circ} \mathrm{C}$ with an optimum at $12^{\circ} \mathrm{C}$ (Müller \& Stache 1989) and has an upper survival temperature of 23 to $24^{\circ} \mathrm{C}$ (Table 2). Thus, most of the Antarctic/ cold-temperate algae have higher temperature demands than endemic Antarctic species (Wiencke \& tom Dieck 1989), but similar growth (Adey 1970, Fortes \& Lüning 1980, Bolton \& Lüning 1982, Rueness \& Tanager 1984) and survival limits (Sundene 1962, Munda \& Lüning 1977, Bolton \& Lüning 1982, Lüning 1984, Luning \& Freshwater 1988) to those of endemic Arctic and Arctic/cold-temperate species.

The more stenothermal temperate species (Iridaea laminarioides, I. undulosa, Desmarestia sp.) grow between ( 0 or) 5 and 15 (to 20 ) ${ }^{\circ} \mathrm{C}$ with optimum rates at 10 and $15^{\circ} \mathrm{C}$ and maximum survival temperatures 
Table 1. Investigated species, location, isolator and date of collection

\begin{tabular}{|c|c|c|c|c|}
\hline $\begin{array}{l}\text { Algal species } \\
\text { Systematic position }\end{array}$ & Location & $\begin{array}{l}\text { Collector } \\
\text { Isolator }\end{array}$ & Date & \\
\hline \multicolumn{5}{|l|}{ A. Antarctic/cold-temperate species } \\
\hline $\begin{array}{l}\text { Ulothrix implexa (Kützing) Kutzing } \\
\text { (Ulotrichales, Chlorophyta) }\end{array}$ & $\begin{array}{l}\text { King George Island } \\
\text { Ardley Bay }\end{array}$ & Wiencke & $29 \mathrm{Jan}$ & 1986 \\
\hline $\begin{array}{l}\text { Ulothrix subflaccida Wille } \\
\text { (Ulotrichales, Chlorophyta) }\end{array}$ & $\begin{array}{l}\text { King George Island } \\
\text { Ardley Bay }\end{array}$ & Wiencke & $28 \mathrm{Jan}$ & 1986 \\
\hline $\begin{array}{l}\text { Enteromorpha bulbosa (Suhr) Montagne } \\
\text { (Ulvales, Chlorophyta) }\end{array}$ & $\begin{array}{l}\text { King George Island " } \\
\text { Sea Elephant Bay }\end{array}$ & Wiencke & $28 \mathrm{Jan}$ & 1986 \\
\hline $\begin{array}{l}\text { Prasiola crispa subsp. antarctica (Kützing) } \\
\text { Knebel f. antarctica (Prasiolales, Chlorophyta) }\end{array}$ & $\begin{array}{l}\text { King George Island } \\
\text { Sea Elephant Bay }\end{array}$ & Wiencke & $27 \mathrm{Jan}$ & 1986 \\
\hline $\begin{array}{l}\text { Urospora penicilliformis (Roth) Areschoug } \\
\text { (Acrosiphoniales, Chlorophyta) }\end{array}$ & $\begin{array}{l}\text { King George Island } \\
\text { Ardley Bay }\end{array}$ & Wiencke & $29 \mathrm{Jan}$ & 1986 \\
\hline $\begin{array}{l}\text { Acrosiphonia arcta (Dillwyn) J. Agardh } \\
\text { (Acrosiphoniales, Chlorophyta) }\end{array}$ & $\begin{array}{l}\text { King George Island } \\
\text { Sea Elephant Bay }\end{array}$ & Wiencke & $29 \mathrm{Jan}$ & 1987 \\
\hline $\begin{array}{l}\text { Geminocarpus geminatus (J. D. Hooker et Harvey) Skottsberg } \\
\text { (Ectocarpales, Phaeophyta) }\end{array}$ & $\begin{array}{l}\text { King George Island } \\
\text { Ardley Bay }\end{array}$ & $\begin{array}{l}\text { Clayton } \\
\text { Wiencke }\end{array}$ & $28 \mathrm{Jan}$ & 1986 \\
\hline $\begin{array}{l}\text { Pilayella Iittoralis (Linnaeus) Kjellmann } \\
\text { (Ectocarpales, Phaeophyta) }\end{array}$ & Diego Ramirez Island & $\begin{array}{l}\text { Westermeier } \\
\text { Wiencke }\end{array}$ & $10 \mathrm{Feb}$ & 1986 \\
\hline 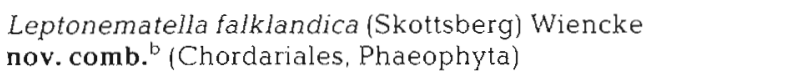 & $\begin{array}{l}\text { Navarino Island } \\
\text { Puerto Williams }\end{array}$ & Wiencke & $10 \mathrm{Feb}$ & 1986 \\
\hline $\begin{array}{l}\text { Scytothamnus fasciculatus (J. D. Hooker et Harvey) Cotton } \\
\text { (Chordariales, Phaeophyta) }\end{array}$ & $\begin{array}{l}\text { Tierra del Fuego } \\
\text { Porvenir }\end{array}$ & $\begin{array}{l}\text { Clayton } \\
\text { Wiencke }\end{array}$ & $16 \mathrm{Feb}$ & 1986 \\
\hline \multirow[t]{2}{*}{$\begin{array}{l}\text { Adenocystis utricularis (Bory) Skottsberg } \\
\text { (Dictyosiphonales, Phaeophyta) }\end{array}$} & $\begin{array}{l}\text { King George Island }{ }^{\star} \\
\text { Ardley Bay }\end{array}$ & $\begin{array}{l}\text { Clayton } \\
\text { Wiencke }\end{array}$ & $2 \mathrm{Feb}$ & 1986 \\
\hline & Diego Ramirez Island & $\begin{array}{l}\text { Westermeier } \\
\text { Clayton, Wiencke }\end{array}$ & $10 \mathrm{Feb}$ & 1986 \\
\hline $\begin{array}{l}\text { Desmarestia menziesii J. Agardh } \\
\text { (Desmarestiales, Phaeophyta) }\end{array}$ & $\begin{array}{l}\text { King George Island } \\
\text { Albatross Island }\end{array}$ & $\begin{array}{l}\text { Clayton } \\
\text { Wiencke }\end{array}$ & $27 \mathrm{Jan}$ & 1986 \\
\hline $\begin{array}{l}\text { Iridaea cordata (Turner) Bory } \\
\text { (Gigartinales, Rhodophyta) }\end{array}$ & $\begin{array}{l}\text { King George Island } \\
\text { Skua Bay }\end{array}$ & Wiencke & 1 Feb & 1987 \\
\hline $\begin{array}{l}\text { Gigartina skottsbergii (Bory) Setchell et Gardner } \\
\text { (Gigartinales, Rhodophyta) }\end{array}$ & $\begin{array}{l}\text { King George Island" } \\
\text { Ardley Bay }\end{array}$ & Wiencke & $28 \mathrm{Jan}$ & 1986 \\
\hline \multicolumn{5}{|l|}{ B. Cold-temperate species } \\
\hline $\begin{array}{l}\text { Enteromorpha clathrata (Roth) J. Agardh } \\
\text { (Ulvales, Chlorophyta) }\end{array}$ & $\begin{array}{l}\text { Navarino Island } \\
\text { Puerto Williams }\end{array}$ & Wiencke & 11 Feb & 1986 \\
\hline $\begin{array}{l}\text { Ectocarpus siliculosus (Dillwyn) Lyngbye } \\
\text { (Ectocarpales, Phaeophyta) }\end{array}$ & $\begin{array}{l}\text { Navarino Island } \\
\text { Puerto Williams }\end{array}$ & Wiencke & 10 Feb & 1986 \\
\hline $\begin{array}{l}\text { Chordaria magellanica Kylin } \\
\text { (Chordariales, Phaeophyta) }\end{array}$ & $\begin{array}{l}\text { Navarino Island } \\
\text { Puerto Williams }\end{array}$ & $\begin{array}{l}\text { Clayton } \\
\text { Wiencke }\end{array}$ & 10 Feb & 1986 \\
\hline $\begin{array}{l}\text { Desmarestia sp. }{ }^{d} \\
\text { (Desmarestiales, Phaeophyta) }\end{array}$ & $\begin{array}{l}\text { Brunswick Peninsula } \\
\text { Fuerte Bulnes }\end{array}$ & $\begin{array}{l}\text { Clayton } \\
\text { Wiencke }\end{array}$ & 14 Feb & 1986 \\
\hline $\begin{array}{l}\text { Petalonia fascia (O. F. Müller) O. Kuntze } \\
\text { (Scytosiphonales, Phaeophyta) }\end{array}$ & Diego Ramirez Island & Wiencke & $10 \mathrm{Feb}$ & 1986 \\
\hline $\begin{array}{l}\text { Scytosiphon lomentaria (Lyngbye) Endlicher } \\
\text { (Scytosiphonales, Phaeophyta) }\end{array}$ & $\begin{array}{l}\text { Navarino Island } \\
\text { Puerto Williams }\end{array}$ & Wiencke & $11 \mathrm{Feb}$ & 1986 \\
\hline $\begin{array}{l}\text { Iridaea laminarioides Bory } \\
\text { (Gigartinales, Rhodophyta) }\end{array}$ & Diego Ramirez Island & $\begin{array}{l}\text { Westermeier } \\
\text { Wiencke }\end{array}$ & $15 \mathrm{Feb}$ & 1986 \\
\hline $\begin{array}{l}\text { Iridaea undulosa Bory } \\
\text { (Gigartinales, Rhodophyta) }\end{array}$ & Diego Ramirez Island & $\begin{array}{l}\text { Westermeier } \\
\text { Wiencke }\end{array}$ & $15 \mathrm{Feb}$ & 1986 \\
\hline \multicolumn{5}{|c|}{$\begin{array}{l}\text { a King George Island is one of the South Shetlands } \\
\text { Basionym: Leptonema falklandicum Skottsberg } 1907 \mathrm{p} .52 \text {. This new combination became necessary after Silva (1959) } \\
\text { established the genus Leptonematella Silva as substitute for the invalid name Leptonema (Reinke 1888) } \\
\text { c Navarino Island is located on the Beagle Channel, opposite Tierra del Fuego } \\
\text { d The species is a ligulate member of the genus Desmarestia }\end{array}$} \\
\hline
\end{tabular}



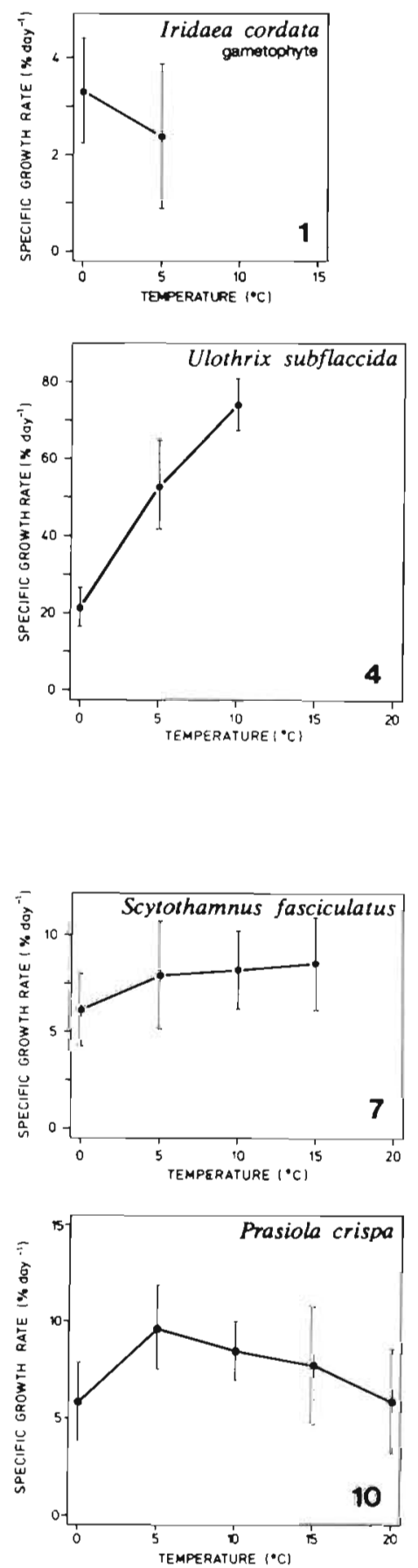
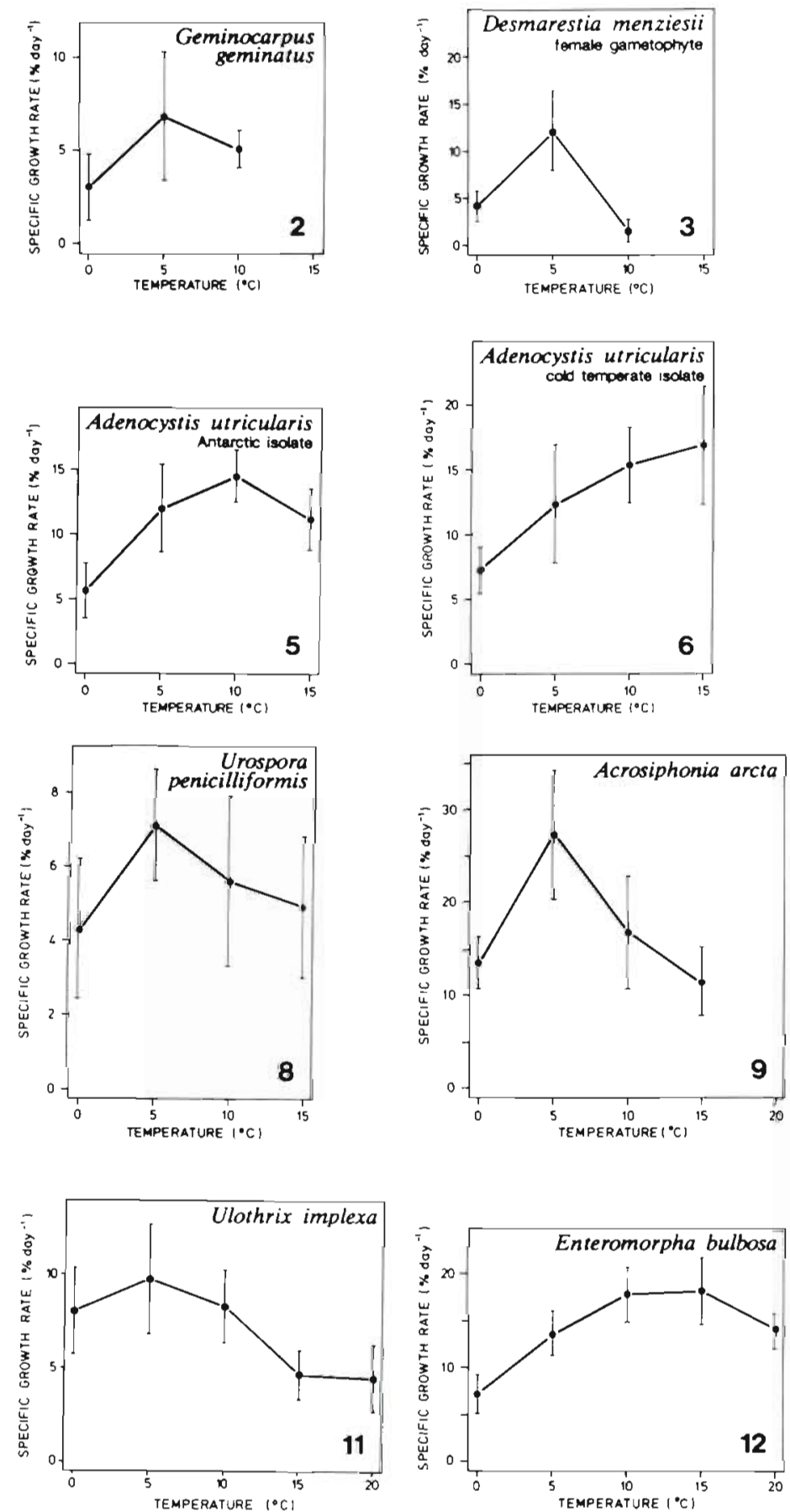

Figs. 1 to 12. Temperature requirements for growth of species from the Antarctic-cold temperate region. Experiments were performed in $5^{\circ} \mathrm{C}$ intervals. No entries: the alga is unable to grow at that particular temperature. Prior to the experiments algae were adapted for $10 \mathrm{~d}$ to the experimental light and temperature conditions. Experiments in Figs. 3, 4 and 9 were performed in Petri dishes at $15 \mu \mathrm{mol} \mathrm{m} \mathrm{m}^{-2} \mathrm{~s}^{-1}, 18: 6 \mathrm{~h}$ light-dark-cycle for a period of 1 to $2 \mathrm{wk}$; all other expenments in large glass beakers at 50 $\mu \mathrm{mol} \mathrm{m} \mathrm{m}^{-2} \mathrm{~s}^{-1}, 18: 6 \mathrm{~h}$ light-dark-cycle for a period of $4 \mathrm{wk}$ or $3 \mathrm{mo}$ (Fig. 7 )

between 17 and $23^{\circ} \mathrm{C}$. More stenothermal characteristics of the same distribution group are only known from the Subantarctic/cold-temperate Durvillaea antarctica which dies above $13.5^{\circ} \mathrm{C}$ (Délépine \& Asensi 1976).
With respect to their growth optima and upper survival temperatures, I. laminarioides, I. undulosa and the Desmarestia sp. are comparable with cold-temperate algae from the northern hemisphere (references given 
Table 2. Temperature tolerance of the investigated species determined in $2 \mathrm{wk}$ exposures to the given temperatures $(x=$

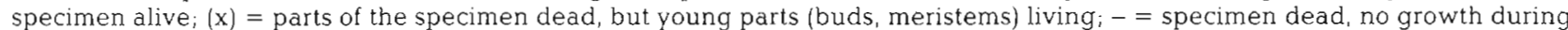
$4 \mathrm{wk}$ postculture under favourable conditions). Every developmental stage was tested in 2 to 4 experimental series, indicated in the table on separate lines

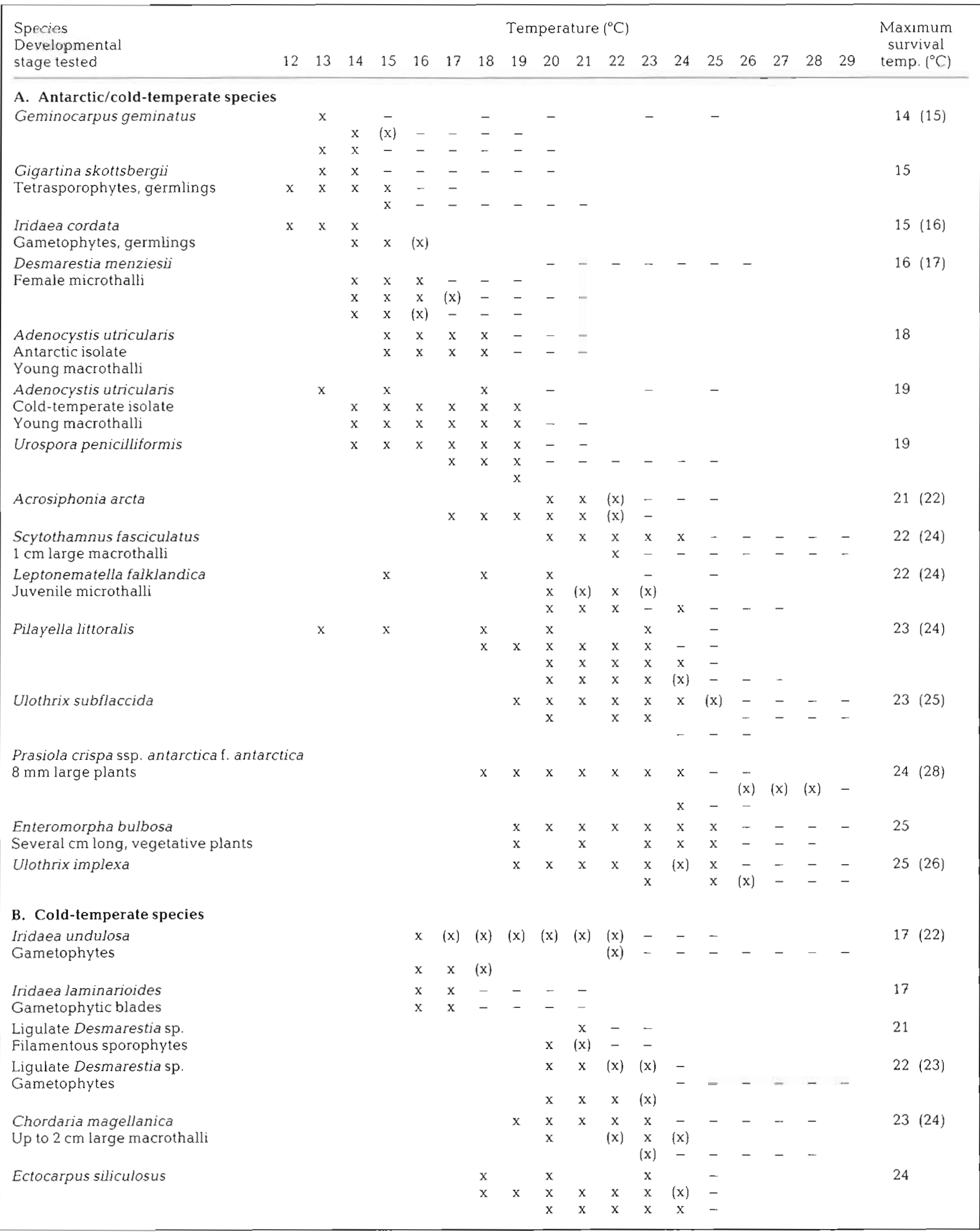


above). The more eurythermal temperate species (Enteromorpha clathrata, Chordaria magellanica, Scytosiphon lomentaria, Ectocarpus siliculosus) grow between 0 and 20 (to 25$)^{\circ} \mathrm{C}$ with optimum values between 5 and $15^{\circ} \mathrm{C}$. They also exhibit an extended upper survival range. These temperature requirements are intermediate between cold- and warm-temperate algae (Akiyama 1965, Branch 1974, Norton 1977, Kapraun 1978, Ohno 1979, Novaczek 1984). All temperate species studied here (except C. magellanica and $E$. siliculosus) show reduced or zero growth rates at $0^{\circ} \mathrm{C}$. This might be an adaptation to the temperature regime in the cold temperate region of South America. They differ in this respect from North Atlantic cold-temperate/Arctic species, which show relatively high growth rates at $0^{\circ} \mathrm{C}$ (Bolton \& Lüning 1982, tom Dieck 1989).

Van den Hoek (1982a, b) and Breeman (1988) showed that the geographic distribution of macroalgae depends on the temperature tolerance and the temperature requirement for growth and reproduction of the different stages in the life cycle of a given alga. Additionally the photoperiod triggering the induction of different phases in the algal life cycle and other factors such as interaction with animals and other plants (Hay 1981, Gaines \& Lubchenco 1982) or incomplete propagation may limit the distribution of macroalgae.

In the following section the geographic distributions of the studied species are analysed in relation to the described temperature demands. The northern distribution of Iridaea cordata is limited by winter temperatures just low enough to allow sufficient growth (Fig. 1; Tables 3 and 4 ; Fig. 21). The populations from the Aucklands and the west coast of South America at $41^{\circ} \mathrm{S}$ are - with respect to the temperature regime at these locations -
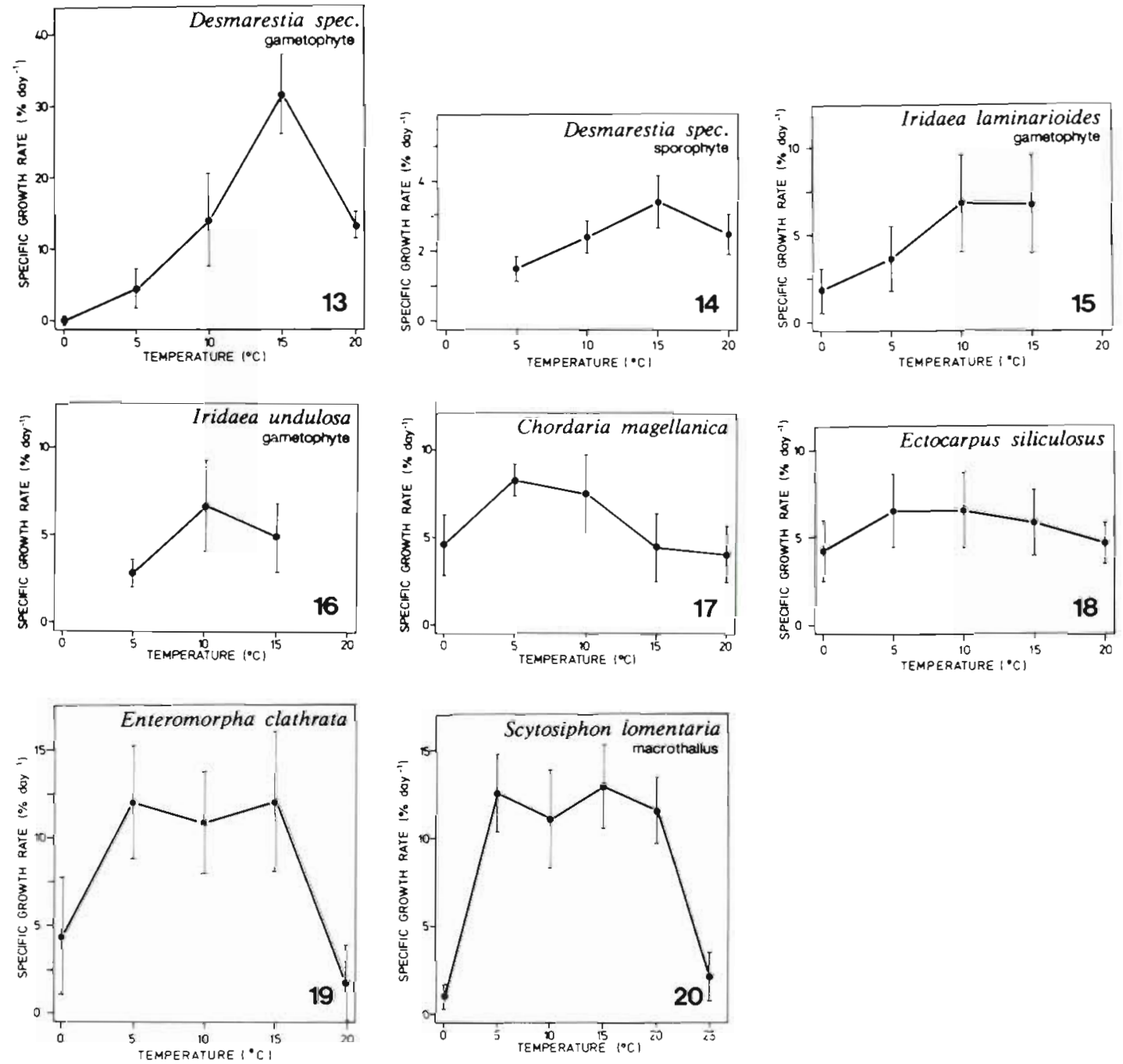

rigs. 13 to 20. Temperature requirements for growth of cold-temperate species from southern Chile. The experiment in Fig. 13 was performed at $15 \mu \mathrm{mol} \mathrm{m} \mathrm{m}^{-2} \mathrm{~s}^{-1}, 18: 6 \mathrm{~h}$ light-dark-cycle for a penod of $2 \mathrm{wk}$; all other experiments at $50 \mathrm{umol} \mathrm{m}^{-2} \mathrm{~s}^{-1}, 18: 6 \mathrm{~h}$ light-dark-cycle for a period of 4 wk. For further information see legend to Figs. 1 to 12 
Table 3. Geographic distribution of the investigated species. Sources: Skottsberg (1907, 1921, 1923, 1941), Laing (1909), Knebel (1935), May (1939), Taylor (1939), Papenfuss (1940), Levring (1944, 1945, 1960), Chapman (1956), Scagel (1957), Lindauer et al. (1961), Pujals (1963), Papenfuss (1964), Asensi (1966), Neushul (1968), Zaneveld (1968), Asensi (1975), Abbott \& Hollenberg (1976), Hansen \& Doyle (1976), Pedersen (1976), Simons (1976), Lamb \& Zimmermann (1977), Santelices \& Abott (1978), Muller (1979), Santelices (1980), Lokhorst \& Trask (1981), Tseng (1983), Seagrief (1984), South (1984), Womersley (1984, 1987), Hay et al. (1985), Wynne (1986), Ramirez et al. (1986), South \& Tittley (1986), tom Dieck (1987), Fletcher (1987), Ricker (1987), Wagner \& Zaneveld (1988). Locations arranged after therr temperature regimes shown in Table 4. Question marks indicate uncertain records

A.gal species Geographic distribution

\section{A. Antarctic/cold-temperate species} Ulothrix implexa

Ulothrix subflaccida

Enteromorpha bulbosa

Prasiola crispa subsp. antarctica f. antarctica

Urospora penicilliformis

Acrosiphonia arcta. Synonyms: Spongomorpha arcta (Dillwyn) Kützing, Cladophora arcta (Dillwyn) Kützing Geminocarpus geminatus

\section{Pilayella Littoralis}

Leptonematella falklandica Scytothamnus fasciculatus

Adenocystis utricularis

Desmarestia menziesii

Iridaea cordata (Turner) Bory

Entity from the Southern Ocean:

Synonyms: I. obovata

I. micans (Bory)

Entity from the Northern hemisphere: Gigartina skottsbergii
Ross Island, Antarctic Peninsula, South Shetlands, Falklands, Tierra del Fuego, South America (east coast). Northern hemisphere: Cold-temperate regions in the Northeast Atlantic and North Pacific

South Shetlands, South Australia. Northern hemisphere: Widely distributed in the North Atlantic

Antarctic Peninsula, South Shetlands, Bouvet, South Georgia, Kerguelen, Macquarie Island, Falklands, Crozet, Tierra del Fuego, Campbell Island, Aucklands, New Zealand, Chatham Island, South America (west coast, $20^{\circ} \mathrm{S}$ ), South Africa, South America (east coast, $35^{\circ} \mathrm{S}$ )

Antarctic Peninsula, Victoria Land, Possession Island and other islands in the Ross Sea, George V Coast, Adelie Coast, Wilkes Land, Queen Mary Coast, Ingrid Christensen Coast, Prince Olav Coast, South Shetlands, South Orkneys, South Sandwich Islands, Bouvet, South Georgia, Kerguelen, Macquarie Island, Falklands, Tierra del Fuego, Southeast Tasmania, New Zealand. On the northern hemisphere the other subspecies occurs: Prasiola crispa ssp. eucrispa (Kützing) Knebel

Antarctic Peninsula, Victoria Land, Ross Island and other islands in the Ross Sea, Wilkes Land, Ingrid Christensen Coast, Mac Robertson Coast, South Shetlands, Heard Island, Kerguelen, Macquarie Island, Falklands, Crozet, Tierra del Fuego, Tasmania. Northern hemisphere: Arctic Ocean and temperate regions of Atlantic and Pacific Ocean

South Shetlands, South Georgia, Kerguelen, Falklands, Tierra del Fuego, Campbell Island, Aucklands. Northern hemisphere: Arctic Ocean and cold-temperate regions of the Atlantic and Pacific Ocean

Antarctic Peninsula, Victoria Land, Wilkes Land, South Shetlands, South Georgia, Kerguelen, Macquarie Island, Falklands, Crozet, Tierra del Fuego, South America (west coast, $52^{\circ} \mathrm{S}$ ), Campbell Island, New Zealand (east coast, $43^{\circ} \mathrm{S}$ ), Juan Fernandez Island

Antarctic Peninsula, South Shetlands, South Georgia, Kerguelen, Macquarie Island, Falklands, Diego Ramirez Island, Tierra del Fuego, Campbell Island, Tasmania, South Australia $\left(140^{\circ} \mathrm{E}\right.$ ), South America (west coast, $\left.30^{\circ} \mathrm{S}\right)$. Northern hemisphere: Arctic Ocean and temperate regions of Atlantic and Pacific Ocean

Wilkes Land, Falklands, Navarino Island

Victoria Land (?), Possession Island, South Shetlands, South Georgia, Kerguelen, Macquarie Island, Falklands, Tierra del Fuego, Campbell Island, Aucklands, South America (east coast, $48^{\circ} \mathrm{S}$ ), South America (west coast, $41^{\circ} \mathrm{S}$ ), Southeast Tasmania, New Zealand (east coast, $43^{\circ} \mathrm{S}$ )

Antarctic Peninsula, Victoria Land (द), South Shetlands, South Orkneys, South Georgia, Kerguelen, Marion Island (?), Macquarie Island, Falklands, Diego Ramirez Island, Crozet, Tierra del Fuego, Campbell Island, Aucklands, Antipodes, Snares, South America (east coast, $48^{\circ} \mathrm{S}$ ), Stewart Island, Southeast Tasmania, New Zealand, Chatham Island, South America (west coast, $17^{\circ} \mathrm{S}$ )

Antarctic Peninsula, Victoria Land, Possession Island, Adelie Coast, Wilkes Land, Enderby Land, Balleny Islands, South Shetlands, South Georgia, Kerguelen, Falklands

Antarctic Peninsula, Victoria Land, Adelie Coast, Possession Island, Ross Island, Wilkes Land, Ingrid Christensen Coast, Balleny Islands, South Shetlands, South Georgia, Heard Island, Kerguelen, Macquarie Island, Falklands, Diego Ramirez Island, Crozet, Tierra del Fuego

Pacific Ocean from Honshu (Japan) to Northern Mexico

Antarctic Peninsula, South Shetlands, Falklands, Tierra del Fuego, South America (west coast, $32^{\circ} \mathrm{S}$ ) 
Table 3 (continued)

\begin{tabular}{|c|c|}
\hline Algal species & Geographic distribution \\
\hline \multicolumn{2}{|c|}{ B. Cold-temperate species } \\
\hline Enteromorpha clathrata & $\begin{array}{l}\text { Falklands, Tierra del Fuego, Aucklands, Antipodes, Snares, New Zealand, South } \\
\text { Africa (?), South, East and West Australia, Northern hemisphere: Arctic to temperate } \\
\text { regions of the Atlantic and Pacific Oceans }\end{array}$ \\
\hline Ectocarpus siliculosus & $\begin{array}{l}\text { South Georgia, Macquarie Island, Falklands, Tierra del Fuego, Aucklands, Snares, } \\
\left.\text { South America (east coast, } 48^{\circ} \mathrm{S} \text { ). New Zealand, Tasmania, South Australia (140 } \mathrm{E}\right) \text {, } \\
\text { South America (west coast, } 20^{\circ} \mathrm{S} \text { ), South Africa, Juan Fernandez Island, South } \\
\text { Australia }\left(129^{\circ} \mathrm{E}\right) \text {, East Australia ( } 27^{\circ} \mathrm{S} \text { ). Northern hemisphere: Greenland, temper- } \\
\text { ate to tropic regions of Atlantic and Pacific Ocean, Mediterranean Sea }\end{array}$ \\
\hline Chordaria magellanica & Tierra del Fuego, Chile $37^{\circ} \mathrm{S}(?)$ \\
\hline $\begin{array}{l}\text { Ligulate Desmarestia sp. } \\
\text { Antarctic entity: }\end{array}$ & Antarctic Peninsula, South Shetlands, South Orkneys, South Georgia \\
\hline Cold-temperate entities: & $\begin{array}{l}\text { Falklands, Crozet, Tierra del Fuego, Campbell Island, Aucklands, Antipodes, Boun- } \\
\left.\text { ties, Snares, Tasmania, South Australia }\left(140^{\circ} \mathrm{E}\right) \text {, South America (west coast, } 30^{\circ} \mathrm{S}\right) \text {, } \\
\text { South Africa }\left(18^{\circ} 30^{\circ} \mathrm{E}\right) \text {. Northern hemisphere: temperate regions of the Atlantic and } \\
\text { Pacific Ocean }\end{array}$ \\
\hline Scytosiphon lomentaria & $\begin{array}{l}\text { South Georgia, Kerguelen, Macquare Island, Falklands, Diego Ramirez Island, } \\
\text { Tierra del Fuego, Campbell Island, Aucklands, Antipodes, South America (east } \\
\left.\left.\text { coast, } 48^{\circ} \mathrm{S}\right) \text {, New Zealand, Tristan da Cunha, South America (west coast, } 30^{\circ} \mathrm{S}\right) \text {, } \\
\text { Southwest Africa }\left(26^{\circ} \mathrm{S}\right) \text {, Juan Fernandez Island, West Australia }\left(28^{\circ} \mathrm{S}\right) \text {, East } \\
\text { Australia }\left(26^{\circ} \mathrm{S}\right) \text {. Northern hemisphere: temperate regions of Atlantic and Pacific } \\
\text { Ocean }\end{array}$ \\
\hline Iridaea laminarioides & $\begin{array}{l}\text { Kerguelen, Falklands, Diego Ramirez Island, Tierra del Fuego, Aucklands, South } \\
\text { America (west coast } 37^{\circ} \mathrm{S}, 32^{\circ} \mathrm{S} \text { ) }\end{array}$ \\
\hline Iridaea undulosa & Falklands, Diego Ramirez Island, Tierra del Fuego, South America (west coast, $37^{\circ} \mathrm{S}$ ) \\
\hline records under. & \\
\hline $\begin{array}{l}\text { Iridaea cillata Kützing } \\
\text { and }\end{array}$ & Tierra del Fuego, South America (west coast, $42^{\circ} \mathrm{S}$ ) \\
\hline Iridaea crispata Bory & 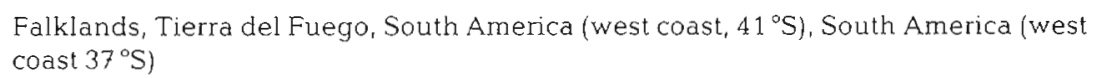 \\
\hline
\end{tabular}

probably ecotypes. I. cordata from the northern hemisphere, however, is a different species (Papenfuss 1964. Leister, cited in Ricker 1987). This alga shows a maximum survival temperature of $20^{\circ} \mathrm{C}$ (next temperature tested: $23^{\circ} \mathrm{C}$ ) determined after an exposure time of $1 \mathrm{wk}$ and the photosynthetic evolution of oxygen as criterion for survival (Luning \& Freshwater 1988). In contrast, southern hemisphere $I$. cordata shows an upper survival temperature of 14 to $16^{\circ} \mathrm{C}$ (Table 2).

The northern boundary of Gigartina skottsbergii remains obscure as summer surface water temperatures at its northernmost location $\left(17.8^{\circ} \mathrm{C}\right.$; Tables 3 and 4) are above the upper survival temperature of $15^{\circ} \mathrm{C}$ (Table 2). One explanation might be that the record on the west coast of South America $\left(32^{\circ} \mathrm{S}\right)$ is out of the distributional range of the species as stated by Setchell \& Gardner (1937)

Geminocarpus geminatus should occur in areas with winter temperatures of $\leq 10^{\circ} \mathrm{C}$ allowing growth of the alga (Fig. 2) and summer temperatures below $15^{\circ} \mathrm{C}$ allowing its survival (Table 2). The material of Juan Fernandez Island (Levring 1941, cited in Ricker 1987) presumably represents a physiological strain as the summer surface water temperature of $20.3^{\circ} \mathrm{C}$ considerably exceeds the maximum survival temperature of 14 to $15^{\circ} \mathrm{C}$ of the studied Antarctic isolate (Tables 2, 3 and 4). Ecoclinal variation is also known from another member of the order Ectocarpales, Ectocarpus siliculosus (Bolton 1983).

Desmarestia menziesii is found from Antarctica to the Falklands with surface water temperatures between 4.2 and $8.5^{\circ} \mathrm{C}$ (Tables 3 and 4 ). The temperature demands of the female gametophyte (Fig. 3 i Table 2) should not be used for the explanation of the phytogeographic distribution since the sporophytes are expected to exhibit a narrower, and thus crucial, temperature range for growth and survival than the gametophytes, as has been shown in Antarctic Desmarestiales. The northern distribution of these species is determined by the low temperature demands 
Table 4. Variation of mean monthly seawater temperatures during the course of the year at the locations listed in Table 3. Source: Gorshkov (1985a, b). Classification of biogeographic regions after South (1979) and Luning (1985)

\begin{tabular}{|lr}
\hline Location & Temperature $\left({ }^{\circ} \mathrm{C}\right.$ ) \\
\hline Antarctic Region: & \\
Antarctic Peninsula (east coast), & \\
Victoria Land, Possession Island, & \\
Ross Island and other islands in & \\
the Ross Sea, George V Coast, & \\
Adelie Coast, Wilkes Land, Queen & \\
Mary Coast, Ingrid Christensen & \\
Coast, Mac Robertson Coast, En- & -1.8 throughout \\
derby Land, Prince Olav Coast & the year \\
Antarctic Peninsula (west coast, & $\leq-1.8$ to -0.2 \\
polar circle), Balleny Islands & $\leq-1.8$ to +1.2 \\
South Shetlands & $\leq-1.8$ to +1.4 \\
South Orkneys & $\leq-1.8$ to +2.1 \\
South Sandwich Islands & -1.5 to +3.0 \\
Bouvet & -0.6 to +4.8 \\
South Georgia & +1.5 to +5.2 \\
Heard Island &
\end{tabular}

Cold-temperate (incl. Subantarctic) Region:

Kerguelen

Macquarie Island

Marion Island

Falklands

Diego Ramirez Island

Crozet

Tierra del Fuego (Strait of Magel-

lan), Navarino Island

South America (west coast, $52^{\circ} \mathrm{S}$ )

Campbell Island

Aucklands

Bounties

Antipodes

Snares

South America (east coast, $48^{\circ} \mathrm{S}$ )

Stewart Island

South America (west coast, $41^{\circ} \mathrm{S}$ )

Southeast Tasmania

New Zealand (east coast, $43^{\circ} \mathrm{S}$ )

Chatham Island

St. Păul

Tristan da Cunha

New Zealand (west coast, $40^{\circ} \mathrm{S}$ )

South Australia $\left(140^{\circ} \mathrm{E}\right)$

Warm-temperate Region

South America (west coast, $37^{\circ} \mathrm{S}$ )

South America (west coast, $32^{\circ} \mathrm{S}$ )

South America (west coast, $30^{\circ} \mathrm{S}$ )

South America (west coast, $20^{\circ} \mathrm{S}$ )

South America (west coast. $17^{\circ} \mathrm{S}$ )

Southwest Africa $\left(26^{\circ} \mathrm{S}\right)$

South America (east coast, $35^{\circ} \mathrm{S}$ )

South Africa $\left(18^{\circ} 30^{\circ} \mathrm{E}\right)$

Juan Fernandez Island

South America (west coast, $12^{\circ} \mathrm{S}$ )

South Australia $\left(129^{\circ} \mathrm{E}\right)$

West Australia $\left(28^{\circ} \mathrm{S}\right)$

East Australia $\left(26^{\circ} \mathrm{S}\right)$

3.2 to 7.0

5.0 to 8.0

4.8 to 8.4

4.2 to 8.5

4.3 to 8.5

5.0 to 9.0

6.0 to 9.4

6.5 to 10.4

8.0 to 10.8

8.0 to 11.0

7.5 to 12.0

7.5 to 12.0

9.7 to 13.0

7.5 to 14.0

10.2 to 14.0

10.0 to 14.8

11.6 to 15.2

11.5 to 16.5

11.6 to 16.6

12.0 to 16.2

12.0 to 18.5

13.0 to 18.8

15.0 to 18.8

11.7 to 15.5

12.4 to 17.8

13.0 to 18.0

14.0 to 19.0

14.8 to 19.8

12.5 to 19.5

12.5 to 20.0

15.5 to 20.0

14.6 to 20.3

15.5 to 20.9

16.5 to 21.8

17.3 to 22.2

17.1 to 22.8

Tropical Region

South East Africa $\left(31^{\circ} \mathrm{S}\right)$

East Australia $\left(27^{\circ} \mathrm{S}\right)$
19.6 to 24.5 19.8 to 26.0 of the sporophytes (Wiencke \& tom Dieck 1989). Thus, in $D$. menziesii a northern boundary with inhibiting high winter temperatures for sporophytic growth is to be expected.

The different temperature demands for growth and survival of Adenocystis utricularis isolates from both sides of the Antarctic convergence (Figs. 5 and 6; Table 2) indicate the development of temperature ecotypes. The northernmost distributional location of the species on the west coast of South America is characterized by the $19.8^{\circ} \mathrm{C}$ summer isotherm (Tables 3 and 4 ). This does not coincide with the upper survival temperature of the macrothallus $\left(19^{\circ} \mathrm{C}\right.$, south Chilean isolate; Table 2). With the supposition that microthalli of this species might exhibit a higher survival temperature than their macrothalli - a generally known phenomenon in algae (Breeman 1988) - a northern lethal boundary determined by the microthallus is most probable.

Lethal boundaries seem to limit the northern distribution of the supralittoral and intertidal species Urospora penicilliformis, Ulothrix implexa, U. subflaccida, Enteromorpha bulbosa, Prasiola crispa ssp. antarctica, Leptonematella falklandica and Pilayella littoralis. The considerable differences between the highest possible summer temperatures in the distribution area of some species and their upper survival temperatures, e.g. $20^{\circ} \mathrm{C}$ versus $25^{\circ} \mathrm{C}$ in Enteromorpha bulbosa, may reflect a reasonable safety limit. According to van den Hoek (1982b) a $20^{\circ} \mathrm{C}$ summer isotherm corresponds with an extreme temperature of $23^{\circ} \mathrm{C}$ at the same location. Moreover water temperatures in the supralittoral and intertidal zone may considerably exceed those in open coastal waters (Biebl \& Mc Roy 1971) thereby shifting the northern distribution boundary of the considered species southwards. Finally the mentioned discrepancy may arise from incomplete dispersal or insufficient collecting.

The maximum survival temperature of Acrosiphonia arcta from both hemispheres is probably the same. An isolate from Heligoland (North Sea) survives 20 to $<23^{\circ} \mathrm{C}$ (Lüning 1984), whereas the Antarctic isolate tolerates 21 to $22^{\circ} \mathrm{C}$ (Table 2 ). The northern boundary of this species in the southern hemisphere is not determined by the temperature limits for growth and survival (Fig. 9; Tables 2, 3 and 4; cf. also van den Hoek $1982 \mathrm{~b})$. In the Northeast Atlantic the southern boundary is probably determined by the temperature demands for reproduction of the unicellular sporophyte (van den Hoek 1982b). This developmental stage is, however, lacking in the Antarctic (Wiencke unpubl.) and Heligoland (Kornmann 1964) populations.

Scytothamnus fasciculatus grows at temperatures $\leq 15^{\circ} \mathrm{C}$ (Fig. 7) but is geographically limited to areas with winter temperatures $\leq 11.6^{\circ} \mathrm{C}$ (Tables 3 and 4 ). This suggests a northern reproductive boundary. In 
support of this view, formation of gametangia took place at $10^{\circ} \mathrm{C}$ and $7 \mathrm{~h}$ light but not at $11^{\circ} \mathrm{C}$ and $9.5 \mathrm{~h}$ light (Clayton 1986). In culture this species develops haploid sporophytes directly from gametophytes at temperatures up to $15^{\circ} \mathrm{C}$ and daylengths up to $12.5 \mathrm{~h}$. But this feature might be of no importance in the field as shown for Scytothamnus australis: chromosome counts of wild specimens revealed a chromosome number approximately double that of cultured gametophytes (Clayton 1986)

The temperature demands for growth and survival of ligulate Desmarestia sp. from Antarctica (Wiencke \& tom Dieck 1989) and southern Chile (this study) differ considerably. The gametophytes of the Antarctic isolate grow at temperatures up to $10^{\circ} \mathrm{C}$, those of the cold temperate isolate up to $20^{\circ} \mathrm{C}$ (Fig. 15). In sporophytes of the Antarctic material growth is possible at temperatures between 0 and $5^{\circ} \mathrm{C}$, whereas the sporophytic growth range in the cold temperate isolate is shifted to temperatures between 5 and $20^{\circ} \mathrm{C}$ with no capacity to grow at $0^{\circ} \mathrm{C}$ (Fig. 14). The maximum survival temperature of the sporophyte from the Antarctic isolate is $13^{\circ} \mathrm{C}$, and is $21^{\circ} \mathrm{C}$ for that from the cold temperate isolate (Table 2 ). These differences as well as certain morphological features (e.g. sporangium morphology; Moe \& Silva 1977. Anderson 1985) support the hypothesis that ligulate Desmarestia sp. on both sides of the Antarctic convergence most probably belong to different species as pointed out earlier (Wiencke \& tom Dieck 1989). The Antarctic isolate is phytogeographically limited to areas with winter surface water temperatures sufficiently low $\left(\leq 5^{\circ} \mathrm{C}\right)$ to allow growth of the sporophyte, the most sensitive stage in the life cycle of this alga. The cold temperate isolate is restricted to areas with winter temperatures $\geq 5^{\circ} \mathrm{C}$ enabling growth of the sporophyte. The northern distribution limit of this entity cannot be a growth boundary as the winter surface water temperatures $\left(13\right.$ to $15.5^{\circ} \mathrm{C}$ i Tables 3 and 4 ) of the northernmost locations of ligulate Desmarestia sp. are considerably below the upper temperature limits for growth $\left(20^{\circ} \mathrm{C}_{i}\right.$ Figs. 13 and 14). The northern boundary may be a composite lethal and reproductive boundary given by the maximum survival temperature of the gametophyte $\left(22\right.$ to $23^{\circ} \mathrm{C}$ i Table 2$)$ and the (unknown) upper temperature limit for reproduction. In support of this view Ramirez et al. (1986) induced gametophyte fertility at temperatures between 5 and $14^{\circ} \mathrm{C}$ (next temperature tested: $20^{\circ} \mathrm{C}$ ) in another ligu-

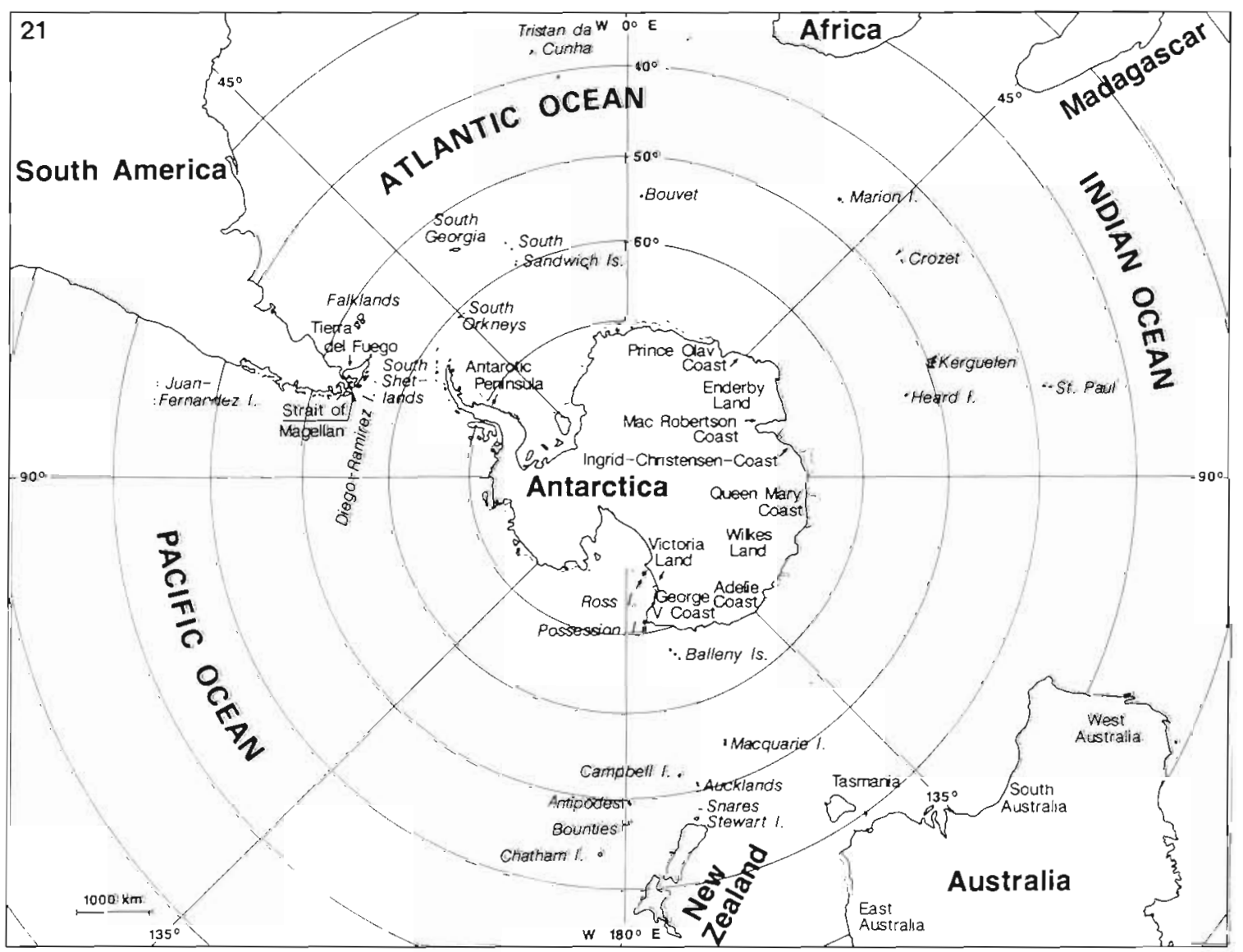

Fig. 21. Map redrawn after Heeren et al. (1972) showing the locations listed in Tables 3 and 4 
late Desmarestia sp. from central Chile. The same factors determine the southern boundary of North Atlantic Desmarestia sp. (van den Hoek 1982b).

The development of species with different degrees of adaptation to the temperature regime south and north of the Antarctic convergence is also evident in the genus Iridaea. The Antarctic/cold-temperate I. cordata grows at temperatures $\leq 5^{\circ} \mathrm{C}$ (Fig. 1), whereas the species from southern Chile, I. undulosa and I. laminarioides, grow between 5 and $15^{\circ} \mathrm{C}$ or 0 and $15^{\circ} \mathrm{C}$, respectively. Thus, as temperatures remain below $5^{\circ} \mathrm{C}$ in Antarctica, I. undulosa is totally excluded from this region. I. laminarioides on the other hand occurs on the Kerguelen Islands with lower temperatures compared to the Falkland Islands, the coldest location where $I$. undulosa can exist (Tables 3 and 4). The reduced rate at $0^{\circ} \mathrm{C}$ may explain why $I$. laminarioides has not yet been found in the Antarctic region. The upper survival temperature of the gametophytic blade $\left(17^{\circ} \mathrm{C}\right.$; Table 2$)$, but not of the holdfasts $\left(22^{\circ} \mathrm{C}\right.$; Table 2$)$ of $I$. undulosa coincides with the $15^{\circ} \mathrm{C}$ summer isotherm at the northern boundary of this species (Tables 3 and 4 ). In contrast, the northern distribution limit of $I$. laminarioides on the west coast of South America $\left(18^{\circ} \mathrm{C}\right.$ summer isotherm; Tables 3 and 4) does not coincide with the temperature limit for growth $\left(15^{\circ} \mathrm{C}\right.$; Fig. 15) nor with the maximum survival temperature of the gametophytic blade (Table 2). This points to the development of temperature ecotypes in the populations of $I$. laminarioides from Diego Ramirez Island (this investigation) and central Chile. Luxoro \& Santelices (1989) obtained high growth rates in gametophytic and tetrasporophytic sporelings at $20^{\circ} \mathrm{C}$ from a central Chilean population $\left(33^{\circ} 29^{\prime}\right.$ S), supporting this hypothesis.

Chordaria magellanica shows a broad temperature range for growth and survival. Its absence from Antarctica and from localities north of Tierra del Fuego is not in accordance with the experimental results. A related species from Heligoland, C. flagelliformis, has a heteromorphic life-cycle with a microthallus probably present throughout the year becoming fertile only in winter (Kornmann 1962). If C. magellanica behaves similarly, its northern distribution limit could be a reproductive boundary.

A similar situation is also evident in Scytosiphon lomentaria. The seasonal development of this species is controlled by photoperiod and temperature, inducing the formation of macrothalli from crusts in spring (Clayton 1976, Luning 1980). So low winter temperatures allowing induction of macrothalli from microthalli rather than temperature growth data (Fig. 20) and maximum survival temperatures (tom Dieck 1987) limit the northern distribution of this alga in the southern hemisphere (cf. also van den Hoek 1982b).
In Ectocarpus siliculosus the development of temperature ecotypes was shown in northern hemisphere isolates from the Arctic to the warm temperate region and in an isolate from Victoria, Australia (Bolton 1983). The Australian isolate grows between 5 and $26^{\circ} \mathrm{C}$ (higher and lower temperatures not tested) with a maximum growth rate at $20^{\circ} \mathrm{C}$. Its maximum survival temperature is $25^{\circ} \mathrm{C}$ (next temperature tested: $28^{\circ} \mathrm{C}$ ). The isolate from southern Chile seems to be another not yet described ecotype of the species as the temperature growth range extends from 0 to $20^{\circ} \mathrm{C}$ with optimum values between 5 and $15^{\circ} \mathrm{C}$ (Fig. 18) and a maximum survival temperature of $24^{\circ} \mathrm{C}$ (Table 2). On the west coast of South America (including Juan Fernandez Island), the northern distribution limit $\left(20.3^{\circ} \mathrm{C}\right.$ summer isotherm; Tables 3 and 4) is determined by the upper survival temperature. Another example of ecotypic variation in relation to temperature may be evident in Enteromorpha clathrata. The studied isolate differed from the European E. clathrata in its capability to grow at $0^{\circ} \mathrm{C}$ (Fig. 7), whereas the Netherlands isolate failed to grow below $12^{\circ} \mathrm{C}$ (Koeman 1985). It should be noted, however, that the taxonomic status on the species level may be uncertain in the genus Enteromorpha.

\section{CONCLUSIONS}

The data presented give an idea of the time periods necessary to develop temperature ecotypes or species with different temperature demands. Acrosiphonia arcta has occurred in 2 disjunct areas in the northern and southern hemisphere at least since the Pleistocene, i.e. for 2 million yr (van den Hoek 1982b) and has not changed its temperature demands for survival since then (see above). The same applies to Desmarestia aculeata, D. viridis, Plocamium cartilagineum and Ahnfeltia plicata from the Northeast Pacific, still showing the same upper survival temperatures as their North Atlantic conspecifics (Lüning \& Freshwater 1988). The proposed dispersal took place after opening of the Bering Strait some 3.5 million yr ago. On the other hand ligulate Desmarestia sp. from both sides of the Antarctic convergence and members of the genus Iridaea from Antarctica, southern Chile and the northern hemisphere differ considerably in their temperature demands for growth and survival (see above). For the development of the considered species differing in their temperature demands long divergence times are to be expected. In particular, taxa with a disjunct Antarctic/cold-temperate distribution are thought to have developed after opening of the Drake Passage and the concomitant temperature lowering in Antarctica 25 to 30 million yr ago (Thenius 1977. Hempel 1987). The evolution of cold water macroalgae is still in 
process today as indicated by the development of temperature ecotypes in Adenocystis utricularis from Antarctica and Southern Chile (see above).

Acknowledgements. A grant from the Deutsche Forschungsgemeinschaft to $\mathrm{K}$. Lüning, Hamburg, is gratefully acknowledged. Thanks go also to the Instituto Antartico Chileno, Santiago de Chile, providing transport, acrommodation and laboratory facilities in Antarctica and to $\mathrm{V}$. Clayton, Melbourne, Australia, as well as to R. Westermeier, Valdivia, Chile, for discussions and help during field work. G. Lokhorst, Leiden, gratefully identified the Ulothrix species. M. Wynne, Ann Arbor, Michigan, and R. Moe, Berkeley, California, USA, gave invaluable advice in the determination of the Gigartinales. The figures were drawn by $K$. Bremer and $G$. Dansauer, Bremerhaven, and parts of the manuscript were typed by $\mathrm{I}$. Lukait, Bremerhaven. Finally we thank C. Langreder for technical assistance and $K$. Lüning, Hamburg, for critically reading the manuscript.

\section{NOTE ADDED IN PROOF}

R. J. Anderson and J. J. Bolton recently published a pertinent paper on another ligulate Desmarestia species: 'Growth and fertility, in relation to temperature and photoperiod, in South African Desmarestia firma (Phaeophyta).' Botanica mar 32: 149-158 (1989). Their findings are in close accordance to the results reported here.

\section{LITERATURE CITED}

Abbott, I. A., Hollenberg, G. J. (1976). Marine algae of California. Stanford University Press, California

Adey, $W H$. (1970). The effects of light and temperature on growth rates in boreal-subarctic crustose corallines. J. Phycol. 6: 269-276

Akiyama, K. (1965). Studies of ecology and culture of Undaria pinnatifida (Harv.) Sur. II. Environmental factors affecting the growth and maturation of the gametophyte. Bull Tohoku reg. Fish. Res. Lab. 25: 143-170

Anderson, R. J. (1985). Morphological and taxonomic relatıonships among branched, ligulate members of the genus Desmarestia (Phaeophyceae, Desmarestiales), with particular reference to South African D. firma. Can. J. Bot. 63 $437-447$

Asensi, A. (1975). La estructura, la distribucion y el cultivo de Scytothamnus fasciculatus (Hook. et Harv.) Cotton (Phaeophyta). Physis (Secc. A, Oceanos sus org.) 34: 269-282

Asensi, A. O. (1966). Guia para reconocer los generos de algas pardas de la Argentina. Contributión del Instituto Antartico Argentino No. 103, Buenos Aires

Biebl, R., Mc Roy, C. P. (1971). Plasmatic resıstance and rate of respiration and photosynthesis of Zostera marina at different salinities and temperatures. Mar. Biol. 8: 48-56

Bolton, J. J. (1983). Ecoclinal variation in Ecotcarpus siliculosus (Phaeophyceae) with respect to temperature growth optima and survival limits. Mar. Biol. 73: 131-138

Bolton, J. J., Lüing, K. (1982). Optimal growth and maximal survival temperatures of Atlantic Laminaria species (Phaeophyta) in culture. Mar. Biol. 66: 89-94
Branch, M. L. (1974). Limiting factors for the gametophytes of three South African Laminariales. Investl Rep. Sea Fish. Branch S. Afr. 104: 1-38

Breeman, A. M. (1988). Relative importance of temperature and other factors in determining geographic boundaries of seaweeds: experimental and phenological evidence. Helgoländer Meeresunters. 42: 199-241

Chapman, V. M. (1956). The marine algae of New Zealand Part I; Myxophyceae and Chlorophyceae. J. Linn. Soc (Bot.) 55: 333-501

Clayton, M. N. (1976). Complanate Scytosiphon lomentaria (Lyngbye) J. Aggardh (Scytosiphonales: Phaeophyta) from Southern Australia: the effects of season, temperature, and daylength on the lite-history. J. exp. Mar. Biol. Ecol. 25: $187-198$

Clayton, M. N. (1986). Culture studies on the life-history of Scytothamnus australis and Scytothamnus fasciculatus (Phaeophyta) with electron microscope observations on sporogenesis and gematogenesis. Br. phycol. J. 21: 371-386

Clayton, M. N., Wiencke, C. (1986). Techniques and equipment for culturing Antarctic benthic marine algae, and for preparing specimens for electron microscopy. Serie Cient. Inst. antarct. chil. (INACH) 34:93-97

Délépine, R, Asensi, A. (1976). Quelques données expérimentales sur l'ecophysiologie de Durvillea antarctica (Cham.) Hariot (Phéophycées). Bull. Soc. phycol. Fr. 21: 65-80

Dieck, I. tom (1987). Temperature tolerance and daylength effects in isolates of Scytosiphon lomentaria (Phaeophyceae) of the North Atlantic and Pacific Ocean. Helgoländer Meeresunters. 41: 307-321

Dieck, I. tom (1989). Vergleichende Untersuchungen zur Ökophysiologie und Kreuzbarkeit innerhalb der digitaten Sektion der Gattung Laminaria Lamour (Phaeophyceae). Ph.D. thesis, University of Hamburg

Fletcher, R. L. (1987). Seaweeds of the British Isles. Vol. 3 Fucophyceae (Phaeophyceae) Part 1. British Museum (Natural History), London

Fortes, M. D., Lüning, K. (1980). Growth rates of North Sea macroalgae in relation to temperature, irradiance and photoperiod. Helgoländer Meeresunters. 34: 15-29

Gaines, S. D., Lubchenko, J. (1982). A unified approach to marine plant-herbivore interactions. II. Biogeography. A. Rev. Ecol. Syst. 13: 111-138

Gorshkov, S. G. (ed.) (1.985a), World ocean atlas. Vol. 1. Pacific Ocean. Pergamon Press, Oxford

Gorshkov, S. G. (ed.) (1985b). World ocean atlas. Vol. 2. Atlantic and Indian Oceans. Pergamon Press, Oxford

Hansen, J. E., Doyle, W T (1976). Ecology and natural history of Iridaea cordata (Rhodophyta, Gigartinaceae): population structure. J. Phycol. 12: 273-278

Hay, C. H., Adams, N. M., Parsons, M. J. (1985). The marine algae of the Subantarctic islands of New Zealand. Natn. Mus. N.Z. misc. Ser. 11:1-70

Hay, M. E. (1981). Herbivory, algal distribution, and mainte:nance of between-habitat diversity on a tropical fringing reef. Am. Nat. 118: 520-540

Heeren, B. C. Tharp, M., Bentley, C. R. (1972). Morphology of the earth in the Antarctic and Subantarctic. Antarctic Map Folio Series 16. Am. Geogr. Soc., New York

Hempel, G. (1987). Die Polarmeere - ein biologischer Vergleich. Polarforschung 57 173-189

Hoek, van den C. (1982a). The distribution of benthic marine algae in relation to the temperature regulation of their life histories. Biol J. Linn. Soc. 18: 81-144

Hoek, van den, C. (1982b). Phytogeographic distribution groups of benthic marine algae in the North Atlantic Ocean. Helgoländer Meeresunters. 35: 153-214 
Kapraun, D. F. (1978). Field and culture studies on growth and reproduction of Callithamnion byssoides (Rhodophyta, Ceramiales) in North Carolina. J. Phycol. 14: 21-24

Knebel, G. (1935). Monographie der Algenreihe Prasiolales. Hedwigia $75: 1-120$

Koeman, R. P. T (1985). The taxonomy of Ulva Linnaeus and Enteromorpha Link (Chlorophyceae) in the Netherlands Drukkerij van Dendoren B. V., Groningen

Kornmann, P. (1962). Die Entwicklung von Chordaria flagelliformis. Helgoländer wiss. Meeresunters. 8: 276-279

Kornmann, P. (1964). Der Lebenszyklus von Acrosiphonia arcta. Helgoländer wiss. Meeresunters 11. 110-117

Laing, R. M. (1909). The marine algae of the Subantarctic Islands of New Zealand. In: Chilton, C. (ed.) The Subantarctic islands of New Zealand, Vol. 2. John Mackay, Gov. Printer, Wellington, p. 493-527

Lamb, I. M., Zimmermann, M. H. (1977). Benthic marine algae of the Antarctic Peninsula. Antarctic Research Series, Vol. 23, Biology of the Antarctic Seas V, Paper V. Am Geophys. Un., Washington, D.C., p. 129-229

Levring, T. (1944). Meeresalgen von den Crozet-Inseln und Kerguelen. Ark. Bot. 31A: 1-31

Levring, T. (1945). Marine algae from some Antarctic and Subantarctic Islands. Lunds Univ. Arsskrift, N.F. Avd. 2, Bd. 41, Nr. 7: 1-36

Levring, $T$ (1960). Contributions to the marine algal flora of Chile. Lunds Univ. Årsskrift, N.F. Avd. 2, Bd. 56, Nr. 10 $1-85$

Lindauer, V W., Chapman, V. J., Aiken, M. (1961). The marine algae of New Zealand. II. Phaeophyceae. Nova Hedwigia 3: 129-350

Lokhorst, G. M., Trask, B. J. (1981). Taxonomic studies on Urospora (Acrosiphoniales, Chlorophyceae) in Western Europe. Acta bot. neerl. 30: 353-431

Luxoro, C., Santelices, B. (1989). Additional evidence for ecological differences among isomorphic reproductive phases of Iridaea laminarioides (Rhodophyta: Gigartinales). J. Phycol. 25: 206-212

Lüning, K. (1980). Control of algal life-history by daylength and temperature. In: Price, J. H., Irvine, D. E. G., Farnham, W F. (eds.) The shore environment, Vol. 2, Ecosystems. Academic Press, London, p. 915-945

Lüning, K. (1984). Temperature tolerance and biogeography of seaweeds: the marine algal flora of Helgoland (North Sea) as an example. Helgoländer Meeresunters. 38: 305-317

Lüning, K. (1985). Meeresbotanik. Verbreitung, Ökophysiologie und Nutzung der marinen Makroalgen. ThiemeVerlag, Stuttgart

Lüning, K., Freshwater, W (1988). Temperature tolerance of northeast Pacific marine algae. J. Phycol. 24: 310-315

May, $V$ (1939). A key to the marine algae of New South Wales. Part II. Melanophyceae (Phaeophyceae). Proc. Linn. Soc. N.S.W. 64: 191-215

Moe, R. L., Silva, P. C. (1977). Sporangia in the brown algal genus Desmarestia with special reference to Antarctic $D$. ligulata. Bull. Jap. Soc. Phycol. 25: 159-167

Munda, I. M., Lüning, K. (1977). Growth performance of Alaria esculenta off Helgoland. Helgoländer wiss. Meeresunters. 29: 311-314

Muller, D. G. (1979). Genetic affinity of Ectocarpus siliculosus (Dillw.) Lyngb. from the Mediterranean, North Atlantic and Australia. Phycologia 18: 312-318

Müller, D. G. Stache, B. C. (1989). Life history studies on Pilayella littoralis (L.) Kjellman (Phaeophyceae, Ectocarpales) of different geographical origin. Botanica mar. 32: $71-78$
Neushul, M. (1968). Benthic marine algae. Am. Geogr. Soc, Antarctic Map Folio Series 10: 9-10, Plate 14, 15

Norton, T A. (1977). Experiments on the factors influencing the geographical distribution of Saccorhiza polyschides and Saccorhiza dermatodea. New Phytol. 78: 625-635

Novaczek, I. (1984). Response of gametophytes of Ecklonia radiata (Laminariales) to temperature in saturating light. Mar Biol. 82: 241-246

Ohno, M. (1979). Culture and field survey of Sargassum piluliferum. Rep. USA Mar. Biol. Inst. 1: 25-32

Ohno, M. (1984). Culture of an Antarctic seaweed, Phyllophora antarctica (Phyllophoraceae, Rhodophyceae). In: Hoshiai, T., Fukuchi, M. (eds.) Proc. of the 6th Symp. on Polar Biology, Nat. Inst. of Polar Research, Tokyo. Mem. natn. Inst. polar Res. Tokyo (Spec. Issue) 32: 112-116

Papenfuss, G. F. (1940). A revision of the South African marine algae in herbarium Thunberg. Symb. bot. Ups. 4 (3): 1-18

Papenfuss, G. F. (1964). Catalogue and bibliography of Antarctic and Subantarctic benthic marine algae. Antarctic Res. Ser. 1. 1-76

Pedersen, P. M. (1976). Marine benthic algae from southernmost Greenland. Meddr. Gronland 199, 3: 1-79

Pujals, C. (1963). Catalogo de Rhodophyta citadas para la Argentina. Revta Mus. argent. Cienc. nat. Bernadino Rivadavia Inst. nac. Invest. Cienc. nat. (Cienc. bot.) III, 1: 1-139

Ramirez, M. E., Müller, D. G., Peters, A. F. (1986). Life history and taxonomy of two populations of ligulate Desmarestia (Phaeophyceae) from Chile. Can. J. Bot. 64: 2948-2954

Reinke, J. (1888). Die braunen Algen (Fucaceen und Phaeosporeen) der Kieler Bucht. Ber. dt. bot. Ges. 6: 14-20

Ricker, R. W. (1987). Taxonomy and biogeography of Macquarie Island seaweeds. British Museum (Natural History), London

Rueness, J., Tanager, T (1984). Growth in culture of four red algae from Norway with potential for mariculture. Hydrobiologia $116 / 117 \cdot 303-307$

Santelices, B. (1980). Phytogeographic characterization of the temperate coast of Pacific South America. Phycologia 19 $1-12$

Santelices, B., Abbott, I. A. (1978). New records of marine algae from Chile and their effect on phytogeography. Phycologia 17: 213-222

Scagel, R. F. (1957). An annotated bibliography of the marine algae of British Columbia and Northern Washington including keys to genera. Bull. Nat. Mus. Can. 150: 1-289

Seagrief, S. C. (1984). A catalogue of South African green, brown and red marine algae. Mem. Bot. Surv. South Africa 47. $1-72$

Setchell, W. A., Gardner, N. L. (1937). Iridophycus with special reference to the South American species. Univ. Calif. Berkeley Publ. Bot. 19: 195-243

Silva, P. C. (1959). Remarks on algal nomenclature. II. Taxon 8: $60-64$

Simons, R. H. (1976). Seaweeds of Southern Africa: guidelines for their study and identification. Fish. Bull. S. Afr. 7: 1-113

Skottsberg, C. (1907). Zur Kenntnis der subantarktischen und antarktischen Meeresalgen. I. Phaeophyceen. In: Nordenskiöld, O. (ed.) Wiss. Ergebnisse der schwedischen Südpolarexpedition 1901-1903, Band IV, Lieferung 6, Stockholm, Lithogr. Inst. des Generalstabs. A. Asher \& Co. Berlin W., Haar/Steinert, A. Eichler, Succir, Paris, Dulau/ Co., London

Skottsberg, C. (1921). Botanische Ergebnisse der schwedischen Expedition nach Patagonien und dem Feuerlande 1907-1909, VIII. Marine Algen I. Phaeophyceae. K. svenska Vetensk Akad. Handl. 61: $56 \mathrm{pp}$

Skottsberg. C. (1923). Botanische Ergebnisse der schwedi- 
schen Expedition nach Patagonien und dem Feuerlande 1907-1909, IX. Marine Algae, 2. Rhodophyceae, K. Svenska Vetensk Acad. Handl. 63: 1-70

Skottsberg, C. (1941). Communities of marine algae in Subantarctic and Antarctic waters. K. Svenska Vetensk Acad. Handl., Tredje Serien, Stockholm, 19, 4: 1-92

South, G. R. (1979). Biogeography of benthic marine algae of the southern oceans. Proc. Int. Symp. on Biogeogr. and Evolution in the Southern Hemisphere, Auckland, July 1978. N.Z. DSIR Information series 137/1: 85-108

South, G. R. (1984). A checklist of marine algae of eastern Canada, second revision. Can. J. Bot. 62: 680-704

South, G. R., Tittley, I. (1986). A checklist and distributional index of the benthic marine algae of the North Atlantic Ocean. Huntsman Marine Laboratory and British Museum. (Natural History), St. Andrews, London

Sundene, O. (1962). The implications of transplant and culture experiments on the growth and distribution of Alaria esculenta. Nytt. Mag. Bot. 9: 55-174

Taylor, W R. (1939). Algae collected by the 'Hassler', 'Albatross and Schmitt Expeditions. II. Marine algae from Uruguay, Argentine, the Falkland Islands, and the Strait of Magellan. Pap. Mich. Acad. Sci. Arts. Lett. 24: 127-164

Thenius, E. (1977). Meere und Länder im Wechsel der Zeiten. Die Paläogeographie als Grundlage für die Biogeographie. Springer-Verlag, Berlin

This article was submitted to the editor
Tseng, C. K. (ed.) (1983). Common seaweeds of China. Science Press, Beijing

Wagner, H. P., Zaneveld, J. S. (1988). The Xanthophyceae and Chlorophyceae of the western Ross Sea, Victoria Land, Antarctica and Macquarie Island collected under the direction of Prof. Dr J. S. Zaneveld (1963-1967). Blumea 33: $141-180$

Wiencke, C. (1988). Notes on the development of some benthic marine macroalgae of King George Island, Antarctica. Ser. cient. Inst. antarct. chil. (INACH) 37: 23-47

Wiencke, C., Dieck, I. tom (1989). Temperature requirements for growth and temperature tolerance of macroalgae endemic to the Antarctic region. Mar. Ecol. Prog. Ser 54 189-197

Womersley, H. B. S. (1984). The marine benthic flora of Southern Australia, Part I. South Australia Govern. Print. Div., Adelaide

Womersley, H. B. S. (1987). The marine benthic flora of Southern Australia, Part II. South Australia Govern. Print. Div. Adelaide

Wynne, M. J. (1986). A check-list of benthic marine algae of the tropical and subtropical western Atlantic. Can. J. Bot. 64: $2239-2281$

Zaneveld, J. S. (1968). Benthic marine algae, Ross Island to Balleny Islands. Am. Geogr. Soc. N.Y., Antarctic Map Foljo Series, Folio 10: 1-12

Manuscript first received: June 2, 1989

Revised version accepted: September 4, 1989 